UDC 621.039:81'255

Yu. Malynovska, Yu. Yesypenko, K. Vlasenko, V. Kovalchuk, I. Bodrova, O. Ved

State Scientific and Technical Center for Nuclear and Radiation Safety, Kyiv, Ukraine

\section{Analysis of Terminology Used to Categorize Power Uprates of Nuclear Power Plants}

Terms used for categorization of power uprates of nuclear power plants (NPPS) are analyzed in the paper. The power uprate program adopted in Ukraine is briefly described to emphasize importance of this area and need to use the appropriate terms. The categories of power uprates adopted by the U.S. NRC and applied by the IAEA are described. They include measurement uncertainty recapture, stretch, and extended power uprates. Translation of these terms into the Ukrainian language based on the analysis is proposed.

Keywords: nuclear power plant, power uprate, safety margins, safety upgrades.

Ю. Г. Малиновська, Ю. В. Єсипенко, К. М. Власенко, В. Ю. Ковальчук, І. В. Бодрова, О. А. Ведь

Аналіз термінології, що застосовується для визначення категорій підвищення потужності атомних електростанцій

Аналізуються терміни, що використовуються для визначення категорій підвищення потужності атомних електростанцій (АEC). Наведено стислий опис програми підвищення потужності АEC в Україні, яка підкреслює важливість цього напрямку та необхідність використання відповідних термінів. Описуються категорії підвищення потужності, прийняті Комісією ядерного регулювання США, а також використовувані МАГАТЕ. Вони охоплюють підвищення потужності за рахунок вищоі точності вимірювань, підвищення потужності в рамках проектних можливостей та розширене підвищення потужності. На основі проведеного аналізу запропоновано переклад цих термінів українською мовою.

Ключов і слов а: атомна електростанція, підвищення потужності, запаси безпеки, заходи з підвищення безпеки

(C) Yu. Malynovska, Yu. Yesypenko, K. Vlasenko, V. Kovalchuk, I. Bodrova, O. Ved, 2017
$\mathrm{T}$ he economic component of nuclear power engineering is one of the most important factors in the development of this industry in Ukraine. It determines the urgency of addressing modern world trends in the field of power uprate, which is less expensive and more efficient than the construction of new power units from the economic point of view. Due to the planned implementation of some types of power uprate, there arose a problem regarding the correct use of new terms in the Ukrainian language in the professional areas. Based on the above, the paper objective is to analyze principles of applying new terms, present correct options for the translation of existing power uprate types and focus on the needed development of technical guidance and introduction of these terms and their definitions into glossaries for unambiguous translation.

The process of increasing the maximum power level at which a commercial nuclear power plant (NPP) may operate is called a power uprate [1]. Power uprates are an economical way of producing more electricity at an NPP and have attracted interest due to increased electricity prices, a situation that is expected to remain [2]. Power uprates have been employed to enhance the output of NPPs for over 30 years in many countries. During that period, advances in technology and the licensing environment enabled the development and continued implementation of standard and new uprate approaches and strategies [2]. Uprating of the existing plants is a highly cost-effective way of bringing on new capacity [3].

Power uprate program in Ukraine. In the search for new economically viable ways to improve the reliability of the indicators of national power plants in the generation of electricity, Ukraine turned to the experience of foreign countries, which in recent years with increasing frequency call on NPP thermal power uprate. Power uprate of the operating NPPs in Ukraine is one of the most economic and effective ways to ensure additional electricity generation using design safety margins and equipment upgrades [4], as was pointed out in the SNRIU Presentation at the Workshop on Nuclear Power Plant Power Uprates conducted by the U.S. NRC in Kyiv in November 2016 (Fig. 1).

Ukraine operates 15 power units, ranks the tenth in the world for this indicator, and takes the seventh place in the installed capacity. In 2016, NPPs produced 81.2 billion $\mathrm{kW} \cdot \mathrm{h}$ of electricity, constituting $52.4 \%$ of the total electricity production in Ukraine. Safety improvement measures are under implementation on a systematic basis at Ukrainian NPPs in compliance with national regulations and recommendations of the International Atomic Energy Agency (IAEA), taking into account best international practices [5].

The Energoatom Company adopted an industrial power uprate program for operating NPPs. A schedule for thermal power uprate of operating VVER-1000 units to $101.5 \%$ and $104 \%$ has been developed and approved. Stage-by-stage power uprate to $101.5 \%$ and $104 \%$ has been planned (for Rivne Unit 2 eventually to $108 \%)$.

Energoatom actively cooperates with Westinghouse regarding power uprate. As known from open sources, Westinghouse signed a Memorandum of Understanding with the Ukrainian Turboatom Company in May 2016, which is one of the leading companies in the production of turbines for nuclear power plants, thermal power plants, and hydroelectric power plants, with the purpose of coordination and cooperation for power uprates of Ukrainian NPPs. In particular, gradual VVER-1000 power uprate to $110 \%$ is planned.

Overview of power uprates in other countries. Numerous power reactors in USA, Belgium, Sweden, etc. have had their generating capacity increased. In Switzerland, the capacity of its five reactors has been increased by $13.4 \%$. In the USA, 

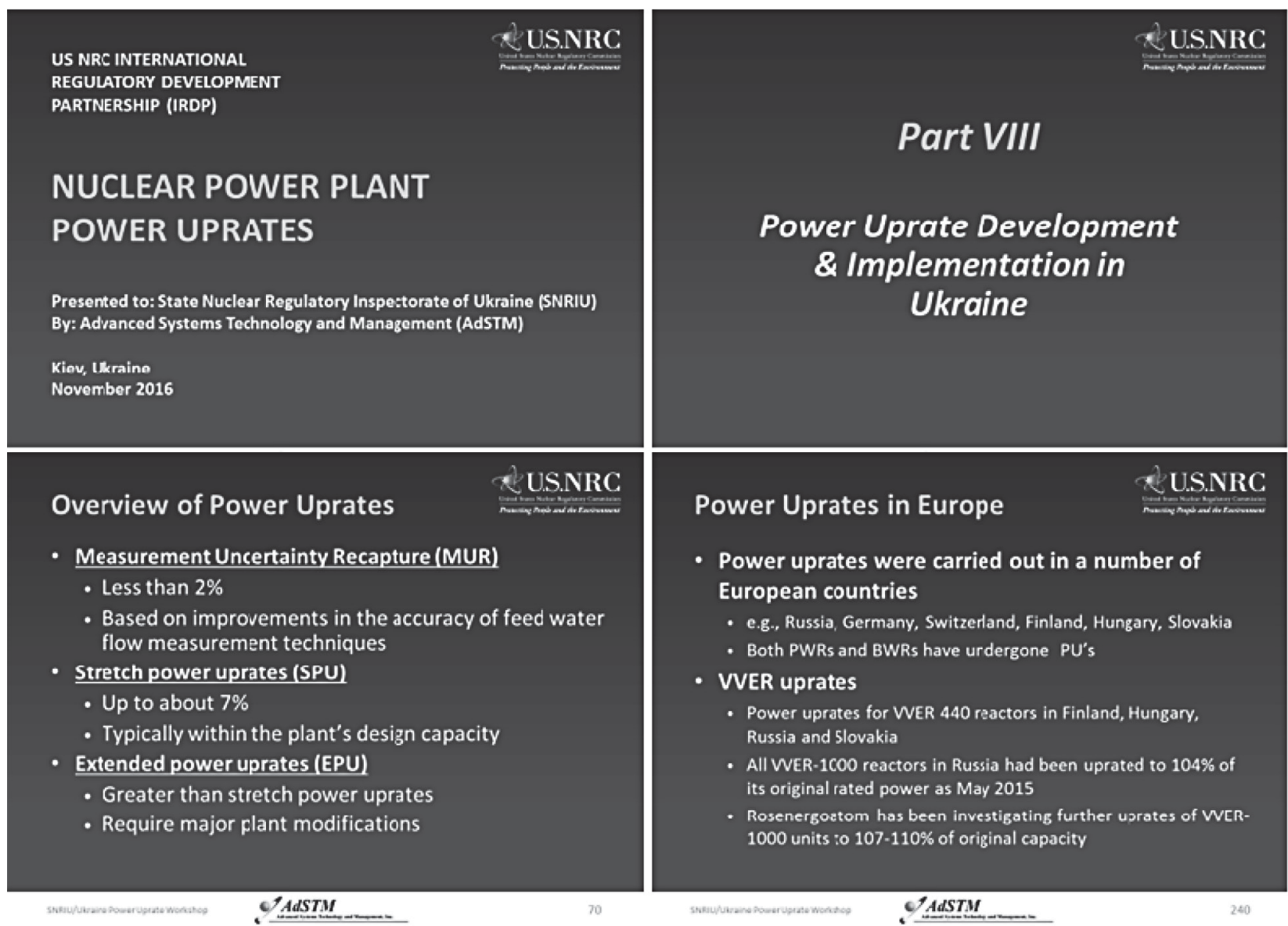

Fig. 1. U.S. NRC presentation on power uprate, Workshop on Nuclear Power Plant Power Uprates, November 2016

the Nuclear Regulatory Commission has approved more than 140 uprates totaling over 6500 MWe since 1977, a few of them "extended uprates" of up to $20 \%$. Spain has had a program to add 810 MWe $(11 \%)$ to its nuclear capacity through upgrading its nine reactors by up to $13 \%$. Most of the increase is already in place. For instance, the Almarez nuclear plant was boosted by $7.4 \%$. Finland boosted the capacity of the original Olkiluoto plant by $29 \%$ to $1700 \mathrm{MWe}$. This plant started with two $660 \mathrm{MWe}$ Swedish BWRs commissioned in 1978 and 1980. The Loviisa plant, with two VVER-440 (PWR) reactors, has been uprated by 90 MWe $(10 \%)$. Sweden's utilities have uprated all three plants. The Ringhals plant was uprated by about $305 \mathrm{MWe}$ over 2006-2014. Oskarshamn 3 was uprated by $21 \%$ to $1450 \mathrm{MWe}$. Forsmark 2 had a 120 MWe uprate (12\%) to 2013 [3].

U.S. NRC categories of power uprates. The U.S. NRC dedicated website (Fig. 2) describes the background, regulatory process, regulations and guidance, status, and types of power uprates [1] as cited below.

Measurement uncertainty recapture power uprates are less than 2 percent and are achieved by implementing enhanced techniques for calculating reactor power. This involves the use of state-of-the-art feedwater flow measurement devices to more precisely measure feedwater flow, which is used to calculate reactor power. More precise measurements reduce the degree of uncertainty in the power level, which is used by analysts to predict the ability of the reactor to be safely shutdown under postulated accident conditions.

Stretch power uprates are typically up to 7 percent and are within the design capacity of the plant. The actual value for percentage increase in power a plant can achieve and stay within the stretch power uprate category is plant-specific and depends on the operating margins included in the design of a particular plant. Stretch power uprates usually involve changes to instrumentation setpoints but do not involve major plant modifications.

Extended power uprates are greater than stretch power uprates and have been approved for increases as high as 20 percent. These uprates require significant modifications to major balance-ofplant equipment such as the high-pressure turbines, condensate pumps and motors, main generators, and/or transformers.

IAEA definitions of power uprates. The IAEA publication "Power Uprate in Nuclear Power Plants: Guidelines and Experience" applies the three terms [2] for power uprates as adopted by the U.S. NRC:

Measurement uncertainty recapture (MUR) uprate. A term applied to the regulatory process of reducing certain emergency core cooling system (ECCS) assumptions regarding reactor power measurement uncertainty from a standard assumption (typically 2-3\%) to a specific value based on the use of more accurate feedwater flow measurement devices. The reduction in the uncertainty assumption can result in an increase in reactor licensed thermal power of $1.2-1.7 \%$ above currently licensed thermal power.

Stretch power uprate (SPU). A term describing an uprate that uses the original plant design excess margin to accommodate an increase in reactor thermal power. Conceptually, such an uprate would not require significant plant modifications since it is ostensibly using existing design margin in the plant 


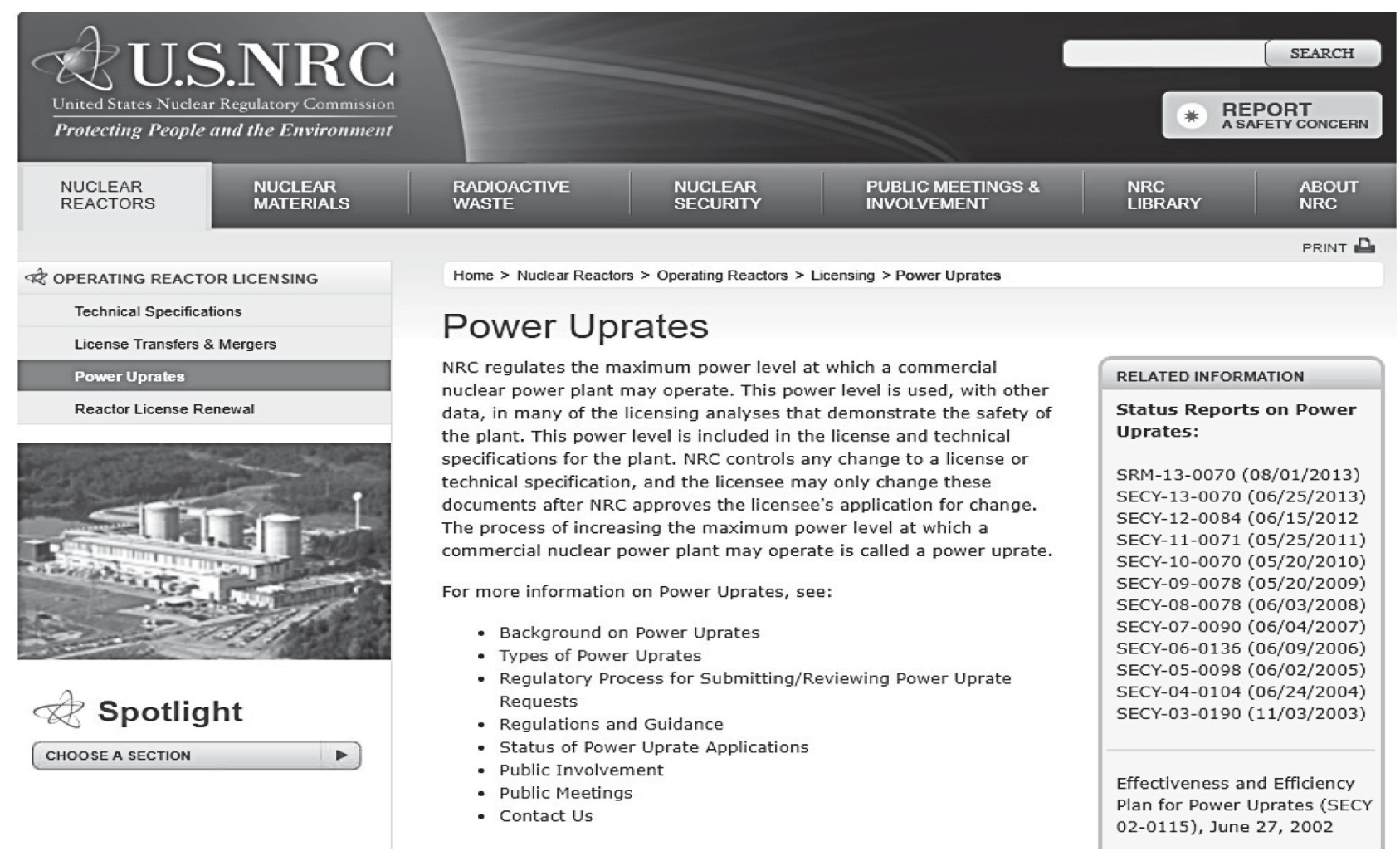

Fig. 2. U.S. NRC website dedicated to power uprate

equipment. In the USA, the Nuclear Regulatory Commission (NRC) has defined a stretch power uprate as any uprate less than $7 \%$ of the originally licensed thermal power of the plant.

Extended power uprate (EPU). A term generally used to describe a large increase in licensed reactor thermal power above the originally licensed thermal power. In the USA, the NRC has defined any uprate of $7 \%$ or higher to be an EPU [2].

Definitions in French power uprate publication. "Power Uprate of a French Nuclear Plant" developed by ENSTA ParisTech, which belongs to the foremost graduate schools of engineering in France, describes advantages, feasibility, and technical studies for power uprates and refers to the U.S. NRC's three categories of power uprates mentioned above, leaving the terms and their abbreviations in English.

Measurement uncertainty recapture (MUR). A significant reduction in uncertainties in thermal heat calculations has reduced the safety margins applied during plant operation. The NRC granted license amendments to increase power by less than $2 \%$, allowing the operator to use these reduced margins.

Stretch power uprates. Some conservative measures were taken during the construction of the plant and were not planned at the time of design and licensing by the safety authorities. Power uprates of this type, up to $7-8 \%$, take advantage of these measures. They are essentially based on new procedures and on modification of the equipment configuration, only a few minor components have to be replaced.

Extended power uprate (EPU). Power uprate of up to $20 \%$ can be achieved, requiring the replacement of many of the plant's heavy components [6].

Ukrainian translation of power uprate terms. Therefore, the terms adopted by the U.S. NRC to categorize power uprates are used internationally. At the Nuclear Power Plant Power Uprates Workshop arranged by the U.S. NRC in Kyiv in November
2016 under International Regulatory Development Partnership, a series of topics relating to power uprates were addressed. They included NRC licensing process for power uprates, detailed description of measurement uncertainty, stretch, and extended power uprates, as well as NRC experience in the development and implementation of power uprate programs. Therefore, the translators faced the need to find the closest equivalents of these terms, which are missing in the Ukrainian language. Using the definitions provided above and material explained at the workshop, the terms were translated as follows:

Measurement uncertainty recapture (MUR) power uprate, which can increase the licensed thermal power by less than 2 percent, is achieved by implementing enhanced techniques for calculating core thermal power, and should have limited effect on plant analyses and equipment, is translated as «підвищення потужності за рахунок вищої точності вимірювань».

Stretch power uprate (SPU), which constitutes up to $7 \%$ above the original licensed thermal power limit for PWRs (up to $5 \%$ for BWRs) and implemented within the original design capacity of the plant but does not involve major plant modifications, is rendered as «nідвищення потужності в межах проектних можливостей енергоблока».

Extended power uprate (EPU), which requires significant changes to the plant, involving engineering, installation, and management systems, multi-disciplined plant modifications, and operational changes, is translated as «розиирене підвищення потужності».

To sum up, the following translation of power uprate types were offered to be used by Ukrainian experts: measurement uncertainty recapture power uprate - підвищення потужності за рахунок вищої точності вимірювань; stretch power uprate підвищення потужності в межах проектних можливостей енергоблока; extended power uprate - розширене підвищення потужності. 


\section{Conclusions}

The relevance and significance of NPP power uprate have been confirmed by numerous examples worldwide. Power uprate of the operating NPPs in Ukraine is one of the most economic and effective ways to ensure additional electricity generation using design safety margins and equipment upgrades as compared to the construction of new power units. Analysis of the terminology used in this area shows that the three categories of power uprates adopted by the U.S. NRC are used internationally. They were extensively presented at the U.S. NRC Workshop on Nuclear Power Plant Power Uprates. These categories include measurement uncertainty recapture, stretch, and extended power uprates. Ways of their translation into the Ukrainian language are offered in the paper. However, this issue requires comprehensive analysis and technical guidance to settle the translation options down in order to avoid misunderstanding and ambiguity among experts in professional areas and to make the use of newly translated terms official.

\section{References}

1. U.S. NRC Power Uprates, URL: https://www.nrc.gov/reactors/ operating/licensing/power-uprates.html

2. Power Uprate in Nuclear Power Plants: Guidelines and Experience. IAEA Nuclear Energy Series No. NP-T-3.9, IAEA, Vienna, 2011, $119 \mathrm{p}$

3. Plans for New Reactors Worldwide, URL: http://www.worldnuclear.org/information-library/current-and-future-generation/plansfor-new-reactors-worldwide.aspx

4. Power Uprate of Nuclear Power Plants Operated by Energoatom, SNRIU Presentation at U.S. NRC Workshop on Nuclear Power Plant Power Uprates, November 2016, Kyiv, Ukraine, 245 p.

5. Report on Nuclear and Radiation Safety in Ukraine for 2016, SNRIU Editorial Board, Kyiv, 2016, 84 p.

6. Augmentation de la Puissance D'une Centrale Nuclŭaire Franзаise, URL: http://www.doyoubuzz.com/var/f/1Z/4G/1Z4GSPJNf5rmQnuxBjREyv8q6egYO3AKc9U0IstXh2 V_WbTpi.pdf

Received 09.08.2017. 